NBER WORKING PAPER SERIES

\title{
ENDOGENOUS MONEY OR STICKY PRICES?
}

\author{
Peter N. Ireland \\ Working Paper 9390 \\ http://www.nber.org/papers/w9390
NATIONAL BUREAU OF ECONOMIC RESEARCH 1050 Massachusetts Avenue Cambridge, MA 02138 \\ December 2002
}

I would like to thank an anonymous referee for very helpful comments and suggestions. Some of this work was completed while I was visiting the Research Department at the Federal Reserve Bank of Cleveland; I would also like to thank the Bank and its staff for their hospitality.This material is also based upon work supported by the National Science Foundation under Grant No. SES-0213461. Any opinions, findings, conclusions or recommendations expressed herein are my own and do not necessarily reflect the views of the Federal Reserve Bank of Cleveland, the Federal Reserve System, the National Bureau of Economic Research, or the National Science Foundation. All data and programs used in this research are available at http://www2.bc.edu/ irelandp. The views expressed herein are those of the authors and not necessarily those of the National Bureau of Economic Research.

(C) 2002 by Peter N. Ireland. All rights reserved. Short sections of text not to exceed two paragraphs, may be quoted without explicit permission provided that full credit including, (C) notice, is given to the source. 
Endogenous Money or Sticky Prices?

Peter N. Ireland

NBER Working Paper No. 9390

December 2002

JEL No. E31, E32, E52

\begin{abstract}
What explains the correlations between nominal and real variables in the postwar US data? Are these correlations indicative of significant nominal price rigidity? Or do they simply reflect the particular way that monetary policymakers react to developments in the real economy? To answer these questions, this paper uses maximum likelihood to estimate a model of endogenous money. This model allows, but does not require, nominal prices to be sticky. The results show that nominal price rigidity, over and above endogenous money, plays a role in accounting for key features of the data.
\end{abstract}

Peter N. Ireland

Boston College

Department of Economics

140 Commonwealth Avenue

Chestnut Hill, MA 02467

and NBER

irelandp@bc.edu 


\section{Introduction}

What explains the relationships observed in the US data on nominal money stocks, nominal interest rates, nominal price inflation, and measures of real economic activity? Do the correlations between these variables provide evidence of true causal effects running from monetary policy actions to changes in the real economy - that is, of significant monetary nonneutralities stemming from some form of nominal price rigidity? Or do the correlations simply reflect the particular way in which monetary policymakers react to developments in the real economy - the workings of what might be called an endogenous money, or reverse causation, channel that operates even in the absence of nominal price rigidity? These questions lie at the heart of monetary economics.

Friedman and Schwartz (1963) present what remains the most celebrated body of evidence in support of the view that changes in the nominal money stock play a causal role in driving fluctuations in real output. Ball and Mankiw (1994), for example, cite Friedman and Schwartz prominently in explaining their preference for sticky-price models of the business cycle. And a host of recent studies, including Hairault and Portier (1993), Yun (1996), Ireland (1997, 2000a, 2001a, 2001b), Rotemberg and Woodford (1997), and Kim (2000), incorporate nominal price 
rigidity into modern, dynamic, stochastic, general equilibrium monetary models. All of these studies imply that monetary instability represents a potentially important source of real instability.

Tobin (1970), by contrast, develops an early argument in support of the alternative, endogenous money view. He constructs a model in which movements in the nominal money stock are correlated with, and even appear to lead, movements in real output over the business cycle. But these patterns arise only because monetary policy responds systematically to nonmonetary shocks that affect output; in Tobin's model, money has no causal role in generating real fluctuations.

Later work advocating the endogenous money view, including King and Plosser (1984), Freeman (1986), Freeman and Huffman (1991), and Freeman and Kydland (2000), highlights the distinction between outside money - meaning the currency and reserves created by the central bank - and inside money - meaning the highly liquid deposits and money market mutual fund shares created by commercial banks, savings banks, and other private financial institutions. These studies develop models in which private financial activity fluctuates along with real economic activity, giving rise to a positive correlation between deposit creation and output even though policy-induced changes in outside money are completely neutral. The emphasis that these studies place on the link between inside money and output is 
motivated partly by King and Plosser's observation that, in the US data, output is more highly correlated with deposits than with currency or the monetary base. On the other hand, King and Plosser do find positive correlations between output and measures of outside money, implying that models such as theirs and Freeman's provide, at best, a partial explanation of the relationships between nominal and real variables. Perhaps, therefore, this focus on the outside-inside money distinction also reflects some discomfort with other specifications, like those found in Greenwood and Huffman (1987), Bryan and Gavin (1994), Finn (1996, 1999), and Gavin and Kydland (1999), that ignore the distinction and simply assume that the central bank acts to increase the money supply following nonmonetary shocks that increase output: why, in an economy in which money is fully neutral, would the central bank want to increase the money supply whenever output rises?

Following the publication of Taylor's (1993) influential essay, however, monetary economists have come to appreciate that most central banks, including the Federal Reserve, conduct monetary policy by managing short-term nominal interest rates rather than some measure of the nominal money supply; in addition, monetary economists have come to appreciate that most central banks, including the Federal Reserve, systematically adjust their nominal interest rate instruments in response to movements in output and inflation. Under nominal interest rate 
rules like the one popularized by Taylor, all movements in the money supply become endogenous and most, if not all, movements in nominal interest rates become endogenous as well. Thus, the observation that Federal Reserve policy can be described by a Taylor rule makes the idea of endogenous money much more plausible: perhaps, by adjusting short-term nominal interest rates in an effort to stabilize output and inflation, Federal Reserve policy has generated correlations that mainly reflect how nominal variables respond to real variables, rather than the way that real variables respond to nominal variables. It is quite curious, therefore, that the workings of Taylor rules have been studied exclusively using models that feature some form of nominal rigidity, such as those developed in the chapters of Taylor (1999).

This paper, accordingly, takes a step back and asks whether a model without nominal rigidity, but with a Taylor-type rule for monetary policy, can account for the key correlations between nominal and real variables exclusively through the endogenous money channel. Put another way, this paper asks whether the assumption of nominal price rigidity is really necessary to achieve a full understanding of the postwar American business cycle, once it is recognized that Federal Reserve policy has worked to make movements in the money supply and in nominal interest rates largely, or perhaps even wholly, endogenous. 
More specifically, the research strategy employed here begins by developing a dynamic, stochastic, general equilibrium model that allows, but does not require, much of the variation in the nominal money supply and in the nominal interest rate to reflect the central bank's deliberate reaction to the nonmonetary shocks that hit the economy. The same model also allows, but again does not require, nominal prices to adjust sluggishly following any shock - monetary or nonmonetarythat hits the economy. The monetary policy rule - a kind of generalized Taylor (1993) rule - provides a channel through which changes in real variables drive movements in nominal variables. The nominal price rigidity, in turn, provides a channel through which changes in nominal variables drive movements in real variables. Thus, the model can potentially attribute the observed correlations between nominal and real variables to endogenous money, sticky prices, or some combination of the two.

The strategy proceeds by estimating the model via maximum likelihood, using postwar US data. A constrained version of the model without nominal price rigidity is then compared to and formally tested against the unconstrained alternative that allows for price rigidity. The results of this econometric exercise indicate whether endogenous money can, by itself, come to grips with the action that is found in the data, or whether nominal price rigidity is needed as well. 


\section{Connections to the Existing Literature}

By asking whether a model with endogenous money can explain the postwar US data and by comparing the empirical performance of model variants with and without sticky prices, this paper extends several branches of the existing literature. First, as mentioned above, Tobin (1970), King and Plosser (1984), Freeman (1986), Greenwood and Huffman (1987), Freeman and Huffman (1991), Bryan and Gavin (1994), Finn (1996, 1999), Gavin and Kydland (1999), and Freeman and Kydland (2000) all ask whether models with endogenous money can account for key facts associated with the American business cycle. None of the models developed in any of these studies is estimated and evaluated with formal econometric techniques, however.

Coleman (1996) estimates a model with endogenous money using a simulated method of moments procedure; his demanding and highly rigorous approach to model evaluation is closest to the one employed here. But Coleman's study, like all of the others mentioned above, considers only a flexible-price model. So while Coleman clearly shows that his flexible-price model leaves some aspects of the data unexplained, he leaves open the question of whether his model's shortcomings might in fact be shared by all existing models of the monetary business cycle, 
including those with sticky prices. This paper, therefore, goes a step beyond Coleman's by asking: what additional features of the data, if any, can be explained once sticky prices are introduced into a model of endogenous money?

Hairault and Portier (1993) and Ellison and Scott (2000) compare the implications of models with and without sticky prices under the assumption that money is exogenous. King and Watson (1996), Rotemberg (1996), and Yun (1996) do the same, while also allowing money to be endogenous. These studies uncover some of the same strengths and weaknesses of sticky-price models that are documented here. But, again, none of the models developed in these studies is estimated with formal econometric techniques and, as a consequence, none can definitively say whether or not the introduction of sticky prices improves the model's fit in a statistically significant way. Here, by contrast, the sticky-price model that is estimated nests a flexible-price variant as a special case. Thus, the econometric exercise performed here provides a clean, formal test of the null hypothesis that prices are fully flexible against the alternative that prices are sticky. By reporting the results of such a test, this paper also goes beyond the contributions of Leeper and Sims (1994), Ireland (1997, 2001a, 2001b), Rotemberg and Woodford (1997), and Kim (2000), each of which estimates a sticky-price model but stops short of explicitly comparing the model's fit to that of a flexible-price specification. 
Rotemberg (1982) develops and estimates a model with quadratic costs of nominal price adjustment that represents, as explained below, a direct precursor to the model used here. Rotemberg also tests the null hypothesis of price flexibility, rejecting this null in favor of the alternative that prices are sticky. Rotemberg's model includes a very simple demand-side specification, however, which is elaborated on in the model used here. And, more important, Rotemberg assumes that money is exogenous, thereby leaving open the question of whether the features of the data that his sticky-price model explains might also be accounted for by a model with flexible prices and endogenous money. Thus, this paper can be viewed as an extension of Rotemberg's that tests the null hypothesis of full price flexibility after allowing for endogenous money.

Finally, Roberts, Stockton, and Struckmeyer (1994), Gali and Gertler (1999), and Sbordone (2002) also extend Rotemberg's (1982) work by developing and estimating models in which prices can either be sticky or flexible and by testing for the statistical significance of parameters measuring the importance of nominal price rigidity. These studies, however, confine their attention to equations governing the behavior of inflation. Here, the analysis again goes a step further by considering a more elaborate model with implications for the behavior of money, interest rates, output, consumption, and investment as well as for inflation. 
Thus, monetary economists have long been interested in explaining the correlations between nominal and real variables using models with endogenous money, price rigidity, or some combination of the two. Past efforts have produced a large body of literature, to which this paper also contributes.

\section{Modeling Strategy}

The model used here embeds Rotemberg's (1982) quadratic specification for the costs of nominal price adjustment into a more detailed, dynamic, stochastic, general equilibrium model with optimizing households and firms and a central bank that is allowed to systematically adjust the short-term nominal interest rate and the money growth rate in response to changes in output and inflation. Similar models appear in Hairault and Portier (1993), Ireland (1997, 2000a, 2001a, 2001b), and Kim (2000); the variant developed here extends those from Ireland (1997, 2000a, 2001a, 2001b) in two basic ways.

First, the model developed here builds on those from previous efforts by introducing a more flexible monetary policy rule that allows the central bank to use the short-term nominal interest rate, the money growth rate, or any linear combination of the two as its principal operating instrument and to adjust its

setting for this instrument in response to changes in output and inflation. This 
more general policy rule nests, as one class of special cases, interest rate rules of the kind proposed by Taylor (1993), according to which the nominal interest rate is set as a function of output and inflation. It also nests, as another class of special cases, money growth rules like those studied by Bryan and Gavin (1994), Finn (1999), and Gavin and Kydland (1999), which call for the money growth rate to be set as a function of output. Finally, the general rule nests, as a third class of special cases, purely exogenous rules for money growth, like those considered by Rotemberg (1982), Hairault and Portier (1993), and Ellison and Scott (2000). Thus, this added flexibility in the theoretical specification allows the data to decide on the importance of monetary endogeneity, as well as on the exact form of monetary endogeneity, when the model is estimated via maximum likelihood.

Second, the model developed here extends those used previously by introducing shocks to the marginal efficiency of investment, like those considered first by Greenwood, Hercowitz, and Huffman (1988) and later by Finn (1999). These investment efficiency shocks are included in the model along with four others: a more conventional productivity shock like the one in Prescott's (1986) real business cycle model, a preference shock like the one in McCallum and Nelson (1999) that enters into the Euler equation linking a representative household's consumption growth to the real interest rate, a preference shock like the one in 
Kim (2000) that acts like a shock to money demand, and a shock to the monetary policy rule. Here, all five shocks are included for the following reason.

Kimball (1995), King and Watson (1996), Casares and McCallum (2000), and Kim (2000) all find that the introduction of adjustment costs for physical capital helps enormously in allowing sticky-price models with optimizing agents match key features of the data. This finding suggests that an adjustment cost parameter for physical capital ought to be estimated together with an adjustment cost parameter for nominal prices in any attempt to quantify the importance of sticky prices in the US economy. Ireland (2001a), however, discovers that data on output, money, inflation, and interest rates are insufficient to identify the capital adjustment cost parameter in a model that is quite similar to the one used here. Accordingly, this study employs data on both consumption and investment, as opposed to just output alone, together with data on real money balances, inflation, and the nominal interest rate, to successfully estimate adjustment cost parameters for both capital and prices.

Since the maximum likelihood procedure uses data on five variables, the model must include at least five exogenous shocks. For with fewer than five shocks, the singularity problem discussed by Ingram, Kocherlakota, and Savin (1994) and Ireland (2000b) arises: the model counterfactually predicts that certain linear 
combinations of the observed variables are perfectly deterministic, so that any attempt to apply maximum likelihood estimation automatically fails. Hence, the introduction of the investment efficiency shock, along with the four others, makes maximum likelihood estimation feasible and, more specifically, helps sharpen the estimate of the key nominal price adjustment cost parameter.

\section{A Model with Endogenous Money and Sticky Prices}

A representative household, a representative finished goods-producing firm, a continuum of intermediate goods-producing firms indexed by $i \in[0,1]$, and a central bank operate in an economy in which time periods are indexed by $t=0,1,2, \ldots$. Each intermediate goods-producing firm produces a distinct, perishable intermediate good; hence, intermediate goods are also indexed by $i \in[0,1]$, where firm $i$ produces good $i$. The model contains enough symmetry, however, to allow the analysis to focus on the behavior of a representative intermediate goods-producing firm, which produces the generic intermediate good $i$.

The representative household carries $M_{t-1}$ units of money, $B_{t-1}$ bonds, and $k_{t}$ units of physical capital into period $t$. At the beginning of the period, the household receives a lump-sum monetary transfer $T_{t}$ from the central bank. Next, the household's bonds mature, providing $B_{t-1}$ additional units of money. The 
household uses some of this money to purchase $B_{t}$ new bonds at the cost of $1 / r_{t}$ units of money per bond, where $r_{t}$ denotes the gross nominal interest rate between $t$ and $t+1$. During period $t$, the household supplies $h_{t}$ units of labor and $k_{t}$ units of capital to the various intermediate goods-producing firms, receiving $W_{t} h_{t}+Q_{t} k_{t}$ units of money in return, where $W_{t}$ denotes the nominal wage and $Q_{t}$ denotes the nominal rental rate for capital.

The household uses its funds to purchase output at the nominal price $P_{t}$ from the representative finished goods-producing firm; the household divides its purchase up into amounts $c_{t}$ and $i_{t}$ to be consumed and invested. In order to transform invested units of the finished good into new units of productive capital, the household must pay an adjustment cost, measured in terms of the finished good and given by

$$
\frac{\phi_{k}}{2}\left(\frac{k_{t+1}}{k_{t}}-1\right)^{2} k_{t},
$$

where $\phi_{k} \geq 0$ governs the size of the capital adjustment cost and where

$$
k_{t+1}=(1-\delta) k_{t}+x_{t} i_{t} .
$$

In this capital accumulation constraint, the depreciation rate satisfies $1>\delta>0$. The disturbance $x_{t}$ is Greenwood, Hercowitz, and Huffman's (1988) shock to the 
marginal efficiency of investment; it follows the autoregressive process

$$
\ln \left(x_{t}\right)=\rho_{x} \ln \left(x_{t-1}\right)+\varepsilon_{x t},
$$

where $1>\rho_{x} \geq 0$ and where the zero-mean, serially uncorrelated innovation $\varepsilon_{x t}$ is normally distributed with standard deviation $\sigma_{x}$.

At the end of period $t$, the household receives $D_{t}$ units of money in the form of dividend payments from the various intermediate goods-producing firms. It then carries $M_{t}$ units of money, $B_{t}$ bonds, and $k_{t+1}$ units of capital into period $t+1$, subject to the budget constraint

$$
\frac{M_{t-1}+B_{t-1}+T_{t}+W_{t} h_{t}+Q_{t} k_{t}+D_{t}}{P_{t}} \geq c_{t}+i_{t}+\frac{\phi_{k}}{2}\left(\frac{k_{t+1}}{k_{t}}-1\right)^{2} k_{t}+\frac{B_{t} / r_{t}+M_{t}}{P_{t}} .
$$

Endowed with one unit of time per period, the representative household acts to maximize the expected utility function

$$
E \sum_{t=0}^{\infty} \beta^{t}\left\{a_{t}[\gamma /(\gamma-1)] \ln \left[c_{t}^{(\gamma-1) / \gamma}+e_{t}^{1 / \gamma}\left(M_{t} / P_{t}\right)^{(\gamma-1) / \gamma}\right]+\eta \ln \left(1-h_{t}\right)\right\},
$$

where the discount factor and the weight on leisure satisfy $1>\beta>0$ and $\eta>0$. The preference shock $a_{t}$ enters into the Euler equation linking the household's 
consumption growth to the real interest rate; McCallum and Nelson (1999) show that this type of disturbance resembles, in equilibrium, a shock to the IS curve in more traditional Keynesian models. And as in Hairault and Portier (1993), Ireland (1997, 2000a, 2001a), and $\operatorname{Kim}$ (2000), the preference parameter $\gamma>0$ measures the absolute value of the interest elasticity of money demand, while the preference shock $e_{t}$ acts like a shock to money demand. Both preference shocks follow autoregressive processes:

$$
\ln \left(a_{t}\right)=\rho_{a} \ln \left(a_{t-1}\right)+\varepsilon_{a t}
$$

and

$$
\ln \left(e_{t}\right)=\left(1-\rho_{e}\right) \ln (e)+\rho_{e} \ln \left(e_{t-1}\right)+\varepsilon_{e t},
$$

where $1>\rho_{a} \geq 0,1>\rho_{e} \geq 0$, and $e>0$ and where the zero-mean, serially uncorrelated innovations $\varepsilon_{a t}$ and $\varepsilon_{e t}$ are normally distributed with standard deviations $\sigma_{a}$ and $\sigma_{e}$.

The representative finished goods-producing firm uses $y_{t}(i)$ units of each intermediate good $i \in[0,1]$, purchased at the nominal price $P_{t}(i)$, to produce $y_{t}$ units of the finished good according to the constant-returns-to-scale technology 
described by

$$
\left[\int_{0}^{1} y_{t}(i)^{(\theta-1) / \theta} d i\right]^{\theta /(\theta-1)} \geq y_{t}
$$

where $\theta>1$. The firm acts to maximize its profits; the first-order conditions for its problem are

$$
y_{t}(i)=\left[P_{t}(i) / P_{t}\right]^{-\theta} y_{t}
$$

for all $i \in[0,1]$, implying that $-\theta$ measures the constant price elasticity of demand for each intermediate good. Competition drives the representative finished goodsproducing firm's profits to zero; this zero-profit condition determines $P_{t}$ as

$$
P_{t}=\left[\int_{0}^{1} P_{t}(i)^{1-\theta} d i\right]^{1 /(1-\theta)} .
$$

The representative intermediate goods-producing firm hires $h_{t}(i)$ units of labor and $k_{t}(i)$ units of capital from the representative household in order to produce $y_{t}(i)$ units of intermediate good $i$ according to the constant-returns-to-scale technology described by

$$
k_{t}(i)^{\alpha}\left[z_{t} h_{t}(i)\right]^{1-\alpha} \geq y_{t}(i)
$$

where $1>\alpha>0$. As in Prescott (1986), the aggregate productivity shock follows 
the autoregressive process

$$
\ln \left(z_{t}\right)=\left(1-\rho_{z}\right) \ln (z)+\rho_{z} \ln \left(z_{t-1}\right)+\varepsilon_{z t}
$$

where $1>\rho_{z} \geq 0, z>0$, and the zero-mean, serially uncorrelated innovation $\varepsilon_{z t}$ is normally distributed with standard deviation $\sigma_{z}$.

Since intermediate goods substitute imperfectly for one another in producing the finished good, the representative intermediate goods-producing firm sells its output in a monopolistically competitive market: during each period $t$, the firm sets the nominal price $P_{t}(i)$ for its output, subject to the requirement that it satisfy the representative finished goods-producing firm's demand at that price, taking the aggregates $P_{t}$ and $y_{t}$ as given. And as in Rotemberg (1982), the representative intermediate goods-producing firm faces a quadratic cost of adjusting its nominal price between periods, measured in terms of the finished good and given by

$$
\frac{\phi_{p}}{2}\left[\frac{P_{t}(i)}{\pi P_{t-1}(i)}-1\right]^{2} y_{t},
$$

where $\phi_{p} \geq 0$ governs the size of the price adjustment cost and where $\pi$ measures the gross steady-state inflation rate. In the special case where $\phi_{p}=0$, the model 
collapses to a flexible-price specification.

The quadratic cost of price adjustment makes the representative intermediate goods-producing firm's problem dynamic; instead of maximizing its profits periodby-period, it seeks to maximize its total market value,

$$
E \sum_{t=0}^{\infty} \beta^{t} \lambda_{t}\left[D_{t}(i) / P_{t}\right]
$$

where $\beta^{t} \lambda_{t}$ measures the representative household's marginal utility of consumption during period $t$ and where $D_{t}(i) / P_{t}$, the real value of the firm's profits and dividend payment during period $t$, is

$$
\frac{D_{t}(i)}{P_{t}}=\frac{P_{t}(i) y_{t}(i)-W_{t} h_{t}(i)-Q_{t} k_{t}(i)}{P_{t}}-\frac{\phi_{p}}{2}\left[\frac{P_{t}(i)}{\pi P_{t-1}(i)}-1\right]^{2} y_{t} .
$$

Finally, the central bank conducts monetary policy by adjusting a linear combination of the short-term nominal interest rate $r_{t}$ and the money growth rate $\mu_{t}=M_{t} / M_{t-1}$ in response to deviations of output $y_{t}$ and inflation $\pi_{t}=P_{t} / P_{t-1}$ from their steady-state values, according to the policy rule

$$
\omega_{r} \ln \left(r_{t} / r\right)-\omega_{\mu} \ln \left(\mu_{t} / \mu\right)=\omega_{y} \ln \left(y_{t} / y\right)+\omega_{\pi} \ln \left(\pi_{t} / \pi\right)+\ln \left(v_{t}\right),
$$


where $\omega_{r}, \omega_{\mu}, \omega_{y}$, and $\omega_{\pi}$ are response coefficients chosen by the central bank and where $r, \mu, y$, and $\pi$ are the steady-state values of $r_{t}, \mu_{t}, y_{t}$, and $\pi_{t}$. The monetary policy shock $v_{t}$ follows the autoregressive process

$$
\ln \left(v_{t}\right)=\rho_{v} \ln \left(v_{t-1}\right)+\varepsilon_{v t},
$$

where $1>\rho_{v} \geq 0$ and the zero-mean, serially uncorrelated innovation $\varepsilon_{v t}$ is normally distributed with standard deviation $\sigma_{v}$. As noted above, this policy rule is considerably more general than those used in previous studies. When $\omega_{r}>0$, $\omega_{\mu}=0, \omega_{y}>0$, and $\omega_{\pi}>0$, it becomes a Taylor (1993) rule for increasing the nominal interest rate in response to higher output or inflation. When $\omega_{r}=0$, $\omega_{\mu}>0, \omega_{y}<0$, and $\omega_{\pi}=0$, it resembles the policy rules from Bryan and Gavin (1994), Finn (1999), and Gavin and Kydland (1999), according to which the central bank increases the money growth rate whenever output rises. Finally, when $\omega_{r}=0, \omega_{\mu}>0, \omega_{y}=0$, and $\omega_{\pi}=0$, it collapses to a purely exogenous, autoregressive specification for money growth, like those appearing in Rotemberg (1982), Hairault and Portier (1993), and Ellison and Scott (2000). Since each of these special cases sets one or more of the response parameters $\omega_{r}, \omega_{\mu}, \omega_{y}$, and $\omega_{\pi}$ equal to zero, it is most convenient to leave each of these parameters 
unconstrained, pinning down their absolute scale by adopting the normalization $\sigma_{v}=0.01$. The policy rule thereby remains quite flexible in terms of the extent to which and the manner in which it allows money and interest rates to respond endogenously to shocks that affect output and inflation.

Pointing out, quite rightly, that the Federal Reserve receives economic data with a lag, McCallum (1993) criticizes policy-rule specifications like the one originally proposed by Taylor (1993) and the variant used here, insofar as they call for an adjustment of the interest rate $r_{t}$ or the money growth rate $\mu_{t}$ in response to contemporaneous changes in output $y_{t}$ and inflation $\pi_{t}$. An alternative formulation, suggested by McCallum's critique, adjusts $r_{t}$ or $\mu_{t}$ in response to expected changes in output and inflation: $E_{t-1} y_{t}$ and $E_{t-1} \pi_{t}$. For the purposes of the present study, however, the rule allowing for a direct response to actual output and inflation, $y_{t}$ and $\pi_{t}$, may be more appropriate. Consider the special case of the model used here in which $\phi_{p}=0$, so that prices are perfectly flexible. In this special case, $y_{t}$ and especially $\pi_{t}$ jump sharply, immediately, and unexpectedly when shocks hit the economy; hence, a policy rule that responds only to $E_{t-1} y_{t}$ and $E_{t-1} \pi_{t}$ severely limits the central bank's ability to react to those shocks. Thus, one should recognize that the policy rule used here implicitly assumes that the central bank can contemporaneously observe and respond to shocks of vari- 
ous kinds. But again, for the purposes of the present study, this informational assumption seems at least as reasonable as the assumption that firms face costs of nominal price adjustment. Taken together, therefore, the assumptions embedded into the model place the flexible-price $\left(\phi_{p}=0\right)$ and sticky-price $\left(\phi_{p}>0\right)$ variants on equal footing, ex-ante, allowing the data to more convincingly discriminate between them, ex-post.

In the model's symmetric equilibrium, all intermediate goods-producing firms make identical decisions, so that $P_{t}(i)=P_{t}, y_{t}(i)=y_{t}, h_{t}(i)=h_{t}, k_{t}(i)=k_{t}$, and $D_{t}(i)=D_{t}$ for all $i \in[0,1]$. In addition, the market-clearing conditions $M_{t}=M_{t-1}+T_{t}$ and $B_{t}=B_{t-1}=0$ must hold. These conditions, together with the first-order conditions for the three representative agents' problems, the laws of motion for the five exogenous shocks, and the central bank's policy rule, form a system of nonlinear difference equations describing the behavior of equilibrium prices and quantities. This system implies that in the absence of shocks, the economy converges to a steady state. After the system is log-linearized around its steady state, the methods of Blanchard and Kahn (1980) yield a solution of the form

$$
\mathbf{s}_{t}=\Pi \mathbf{s}_{t-1}+\Omega \varepsilon_{t}
$$


and

$$
\mathbf{f}_{t}=\mathbf{U} \mathbf{s}_{t}
$$

In the solution, the vector $\mathbf{s}_{t}$ contains the model's state variables, which include the capital stock $k_{t}$ and lagged real balances $m_{t-1}=M_{t-1} / P_{t-1}$ as well as the five exogenous shocks $a_{t}, e_{t}, x_{t}, z_{t}$, and $v_{t}$; lagged real balances enter the state vector because prices are sticky. The vector $\varepsilon_{t}$ contains the five innovations $\varepsilon_{a t}$, $\varepsilon_{e t}, \varepsilon_{x t}, \varepsilon_{z t}$, and $\varepsilon_{v t}$, which are assumed to be mutually uncorrelated as well as serially uncorrelated. The vector $\mathbf{f}_{t}$ contains the model's flow variables, which include consumption $c_{t}$, investment $i_{t}$, inflation $\pi_{t}$, and the nominal interest rate $r_{t}$. Finally, the matrices $\boldsymbol{\Pi}, \boldsymbol{\Omega}$, and $\mathbf{U}$ have elements that depend on the parameters describing private agents' tastes and technologies as well as the parameters of the central bank's policy rule. The constraints linking the elements of $\Pi, \Omega$, and $\mathbf{U}$ to the underlying parameters of the theoretical model cannot be written in closed form and must instead be derived through numerical implementation of the Blanchard-Kahn solution procedure. 


\section{Empirical Strategy}

The model's solution takes the form of a state-space econometric model, driven by the five exogenous shocks $a_{t}, e_{t}, x_{t}, z_{t}$, and $v_{t}$. Hence, its parameters may be estimated via maximum likelihood, using the methods outlined by Hamilton (1994, Ch.13), with data on as many as five variables, while still avoiding the singularity problem discussed by Ingram, Kocherlakota, and Savin (1994) and Ireland (2000b). The five series used here are those for consumption, investment, real money balances, inflation, and the short-term nominal interest rate.

As explained above, data on both consumption and investment are used, rather than data on output alone, in hopes of obtaining the best possible estimate of the capital adjustment cost parameter $\phi_{k}$. Kimball (1995), King and Watson (1996), Casares and McCallum (2000), and Kim (2000) all show that capital adjustment costs interact strongly with nominal price adjustment costs in allowing stickyprice models with optimizing agents match key features of the data. These studies therefore imply that data that provide a sharp estimate of the capital adjustment cost parameter $\phi_{k}$ will also provide a sharp estimate of the price adjustment cost parameter $\phi_{p}$. And since the sticky-price model developed here collapses to a flexible-price specification when $\phi_{p}=0$, a sharp estimate of $\phi_{p}$ should, in turn, 
allow for the most informative test of the null hypothesis, suggested by the strict endogenous money view, that $\phi_{p}=0$.

Thus, in the US data, consumption is measured by real personal consumption expenditures, while investment is measured by real gross private domestic investment. These two series represent the broadest measures of consumption and investment in the National Income and Product Accounts. Real money balances are calculated by dividing the M2 money stock by the GDP deflator, and inflation is calculated as changes in the GDP deflator. Finally, the short-term nominal interest rate is measured by the three-month Treasury bill rate. All of these data, except for the interest rate, are seasonally adjusted. The series for consumption, investment, and real balances are expressed in per-capita terms by dividing by the civilian noninstitutional population, age 16 and over. The data are quarterly and run from 1959:1 through 2000:4.

Several data-related issues must be tackled prior to estimating the model. First, a fundamental change in Federal Reserve policy is widely believed to have occurred soon after Paul Volker's appointment as Chairman in August 1979. The idea that this regime shift worked to alter the correlations between nominal and real variables in the US data appears both in the literature on endogenous money (see, for example, Bryan and Gavin 1994 and Gavin and Kydland 1999) and in 
the literature that emphasizes the importance of sticky prices (see Clarida, Gali, and Gertler 2000). Thus, to allow for the possibility that the policy parameters $\mu, \omega_{r}, \omega_{\mu}, \omega_{y}$, and $\omega_{\pi}$ change, the full sample period is divided into two disjoint subsamples, the first running from 1959:1 through 1979:2 and the second running from 1979:3 through 2000:4. The entire model is estimated with data from each subsample.

Second, distinct upward trends appear in the data for consumption, investment, and real money balances per capita, reflecting the secular growth of the US economy. The model, by contrast, implies that each of these variables fluctuates around a constant mean. Ireland (1997) accounts for trends in data for output and real balances by adding a deterministic trend to the productivity variable $z_{t}$. The model then implies that all real variables grow at the same rate $g$ along a balanced growth path, where $g$ may be estimated together with the other parameters describing tastes and technologies. Here, the use of data on consumption and investment make this approach problematic, since in both subsamples, investment grows at a distinctly faster rate than consumption. Moreover, the Federal Reserve's redefinition of its M2 monetary aggregate in 1996, discussed by Orphanides and Porter (2000), together with the unusual weakness in M2 growth during the early 1990s, discussed by Mehra (1997), introduce differential 
trends into the series for real balances as well. More specifically, for the pre-1979 subsample, regressions of the logarithm of each variable on a constant and a time trend yield slope coefficients of 0.0073 for investment, 0.0055 for consumption, and 0.0046 for real balances. For the post-1979 subsample, the same regressions yield slope coefficients of 0.0084 for investment, 0.0053 for consumption, and 0.0025 for real balances. Rather than complicating the theoretical model in a way that explains these apparent departures from balanced growth, the linearly detrended series are used to estimate the model instead.

Third, even with data on five variables, several of the model's parameters remain unidentified and must therefore be fixed prior to estimation. The parameter $\eta$, for example, measures the weight on leisure in the representative household's utility and cannot be estimated without data on employment; the setting $\eta=1.5$ implies that the household spends about one-third of its time working in the model's steady state. The depreciation rate $\delta$ cannot be estimated without data on the capital stock; the setting $\delta=0.025$ implies an annual depreciation rate of about 10 percent. Finally, the parameter $\theta$, determining the steady-state markup of price over marginal cost, cannot be estimated without data on wages; the setting $\theta=6$ implies a steady-state markup of 20 percent. 


\section{Estimates, Tests, and Diagnostics}

Table 1 presents maximum likelihood estimates of the model's 21 remaining parameters for both the pre-1979 subsample running from 1959:1 through 1979:2 and the post-1979 subsample running from 1979:3 through 2000:4. The standard errors, also shown in table 1, correspond to the square roots of the diagonal elements of negative one times the inverted matrix of second derivatives of the maximized $\log$ likelihood function.

Looking first at the parameters describing tastes and technologies, the estimates of the representative household's discount factor $\beta$ exceed 0.99 for both subsamples. The estimates of $\gamma$ imply an interest elasticity of M2 demand equal to -0.074 for the pre-1979 period and -0.035 for the post-1979 period. The estimate of $\alpha$, measuring capital's share in the production function for intermediate goods, equals 0.20 for the first subsample and 0.21 for the second subsample.

Turning next to the parameters of the monetary policy rule, the estimates of $\mu$ translate into annualized, steady-state money growth rates of 4.5 percent before 1979 and 3.6 percent after 1979. The estimates of $\omega_{r}, \omega_{\mu}$, and $\omega_{\pi}$ are large for both subsamples, allowing for at least two possible interpretations of Federal Reserve policy before and after 1979. First, Federal Reserve policy can be described 
as following a modified Taylor (1993) rule that adjusts the short-term nominal interest rate in response to deviations of money growth and inflation, instead of output and inflation, from their steady-state values. Alternatively, Federal Reserve policy can be characterized as one of Poole's (1970) "combination policies" that adjusts a linear combination of the interest rate and the money growth rate to achieve a target for inflation. On the other hand, the small estimates of $\omega_{y}$ from both subsamples contradict the endogenous money specifications of Bryan and Gavin (1994), Finn (1999), and Gavin and Kydland (1999), all of which have the money growth rate responding directly to changes in output. Note, however, that these small estimates of $\omega_{y}$ need not imply that the endogenous money channel is unimportant in explaining the correlations between money growth, interest rates, and output since, to the extent that output is correlated with inflation, the policy response of money growth and interest rates to inflation will also generate reduced-form correlations between these variables and output.

The estimates of $e$ and $z$ allow the steady-state values of real balances and output in the model to match the average values of detrended real balances and output in the data. The estimates of $\rho_{a}, \rho_{e}, \rho_{x}, \rho_{z}$, and $\rho_{v}$ imply that the model's exogenous shocks are quite persistent. And among the estimates of the standard deviations of the innovations to the shocks, the large estimate of $\sigma_{x}$ for the post- 
1979 period deserves special mention: evidently, large investment efficiency shocks help the model explain the investment boom that lifted the ratio of investment to consumption from 18 percent in 1991:2 to 29 percent in 2000:4.

Finally, consider the capital and price adjustment cost parameters $\phi_{k}$ and $\phi_{p}$. The estimates of both parameters rise across subsamples, suggesting the presence of increased real and nominal rigidity in the post-1979 period, but appear quite sizeable even for the earlier period. Of special interest here, of course, are tests of the null hypothesis that $\phi_{p}=0$. In the case where $\phi_{p}=0$, the model collapses to a flexible-price specification; hence, a test of the null that $\phi_{p}=0$ represents a test of whether sticky prices, over and above endogenous money, are really necessary in allowing the model to explain the behavior of nominal and real variables in the US data. Under the null hypothesis that $\phi_{p}=0$, the Wald statistic formed by squaring the ratio of the point estimate of $\phi_{p}$ to its standard error is asymptotically distributed as a chi-square random variable with one degree of freedom. For both subsamples, in fact, the $p$-value for the Wald test of $\phi_{p}=0$ is less than 0.05 .

Calculating the standard errors reported in table 1 involves two steps, numerically evaluating the matrix of second derivatives of the maximized log likelihood function and inverting that large matrix having elements of varying magnitudes, both of which may introduce approximation error into the Wald statistic described 
above. Likelihood ratio tests, however, can be performed without reference to the standard errors and yield, as the useful by-products displayed in table 2, parameter estimates for the flexible-price model that results when the constraint $\phi_{p}=0$ is imposed. With $\phi_{p}=0$ imposed, the maximized value of the log likelihood falls from 1466.7 to 1442.4 for the pre-1979 subsample and from 1568.3 to 1521.8 for the post-1979 subsample. Again under the null hypothesis that $\phi_{p}=0$, the likelihood ratio statistic formed by doubling the difference between the unconstrained and constrained log likelihood functions is asymptotically distributed as a chi-square random variable with one degree of freedom. Now, for both subsamples, the $p$-value for the likelihood ratio test of $\phi_{p}=0$ is less than 0.01 . For both subsamples, therefore, the introduction of sticky prices yields a statistically significant improvement in the model's ability to fit the data.

But precisely which features of the data are explained by the unconstrained model, with sticky prices, but not by the constrained model, with flexible prices? To answer this question, table 3 and figures 1-4 present sets of diagnostic statistics, suggested by McCallum (2001), which assist in evaluating the empirical performance of each model variant for each subsample of data. Table 3 compares the standard deviations of four key variables - detrended output (defined in both the model and the data as the sum of detrended consumption and detrended in- 
vestment), nominal money growth, inflation, and the nominal interest rate-as implied by each of the estimated models and as seen in the US data. Figures 1-4, meanwhile, plot the vector autocorrelation functions for the same four variables in the models and the data. Looking at statistics for aggregate output, instead of consumption and investment separately, and for nominal money growth, instead of real money balances, keeps the presentation more concise and also makes the results easier to interpret: correlations between real output and nominal money growth, for instance, are more familiar to monetary economists than correlations between real consumption and real money balances. In both the table and the figures, the statistics for the data correspond to those implied by an unconstrained, fourth-order vector autoregression for detrended output, money growth, inflation, and the interest rate; Fuhrer and Moore (1995) also use unconstrained vector autoregressions to summarize the data in this way.

Table 3, containing the standard deviations, brings to light the same weakness of the sticky-price model that is emphasized by Ellison and Scott (2000): for both periods, the sticky-price model overstates the volatility of output. For the pre-1979 subsample, in fact, the constrained, flexible-price model comes closer than the unconstrained, sticky-price model to matching the volatilities of all four variables. For the second subsample, however, the sticky-price model does better 
in matching standard deviations from the data, except for the case of output.

But while table 3 tells a mixed story about the empirical performance of the sticky-price model, figures 1-4 show that the sticky-price model does much better than the flexible-price model in matching the correlations between nominal and real variables at various leads and lags. Comparing figures 1 and 3 for the pre-1979 subsample, and comparing figures 2 and 4 for the post-1979 subsample, reveals that the sticky-price model reproduces many more of the correlations, found in the data, between output and lags of money growth, inflation, and interest rates. For the pre-1979 period, for example, only the sticky-price model captures what King and Watson (1996) call the "inverted leading indicator" property of the nominal interest rate, as reflected in the negative correlation between output and lagged interest rates. And for the post-1979 period, only the sticky-price model comes close to explaining the large positive correlations between output and lagged money growth rates that appear in the data.

Surprisingly, perhaps, the flexible-price model actually does better than the sticky-price model in reproducing the degree of inflation persistence, as measured by the correlation of inflation with its own lagged values, found in the pre-1979 data. The flexible-price model attributes this inflation persistence to persistence in the exogenous shocks, particularly in the preference shock $a_{t}$. For the post-1979 
period, however, the inflation persistence implied by the sticky-price model comes closer to that seen in the data. Thus, while the introduction of sticky prices does not improve the model's empirical performance along all dimensions, on balance it yields a clear improvement in overall fit.

But despite these differences in empirical performance, which lead the data to clearly prefer the unconstrained, sticky-price model to the constrained, flexibleprice model, some quantitative implications are shared by both versions of the model. Tables 4 and 5, for example, break down the variances in detrended output, money growth, inflation, and the nominal interest rate into orthogonal components attributed to each of the models' five exogenous shocks. Some of the results of this variance decomposition differ across models and subsamples. But for both subsamples, neither the sticky-price model nor the flexible-price model attributes more than one percent of the variances of output and the interest rate to the policy shock $v_{t}$. Policy shocks do account for nonnegligible fractions of the variances of money growth and inflation. But looking across results for each model and each subsample, the percentage of the variances of money growth and inflation explained by the policy shock never exceeds 40 percent.

Thus, both the sticky-price model and the flexible-price model imply that virtually all of the variation in real variables, and most of the variation in nominal 
variables, found in the postwar US data come from sources other than monetary policy shocks. Put another way, although the sticky-price model allows nominal disturbances to have potentially important effects on real variables, the estimates from that model also imply that monetary policy shocks have played a very small role in driving business cycles in the postwar US economy. Similar conclusions emerge from empirical studies, such as Leeper, Sims, and Zha (1996), that use more conventional vector autoregressions to identify the effects of monetary policy shocks in the US data; and McCallum (2001) also emphasizes that in theoretical models like the one used here, the systematic component of monetary policy, as summarized by settings for the coefficients $\omega_{r}, \omega_{\mu}, \omega_{y}$, and $\omega_{\pi}$, plays a far more important role than monetary policy shocks in shaping the dynamic behavior of key macroeconomic variables. But here, building on these earlier insights, the results also suggest that the null hypothesis that $\phi_{p}=0$ is rejected, thereby lending support to the sticky-price model, based mainly on information about the Federal Reserve's - and more generally the US economy's - response to nonmonetary shocks.

Finally, figures 1-4 illustrate how some of the correlations between nominal and real variables change across the pre-1979 and post-1979 subsamples. In pre1979 data, for example, detrended output is negatively correlated with lagged 
money growth; in post-1979 data, this correlation becomes positive. And the negative correlation between output and the lagged interest rate, emphasized as a key stylized fact in the study by King and Watson (1996), appears here in the pre1979 data but not in the post-1979 data. Bryan and Gavin (1994) and Gavin and Kydland (1999) focus on changing correlations such as these, attributing them to the shift in monetary policy marked by Paul Volker's arrival at the Federal Reserve in August 1979. Here, the parameter estimates from tables 1 and 2 can be used to test this hypothesis.

If the changing correlations found in the data primarily reflect changes in Federal Reserve policy, then instability ought to appear in the estimates of one or more of the model's policy parameters $\mu, \omega_{r}, \omega_{\mu}, \omega_{y}, \omega_{\pi}$, and $\rho_{v}$. Thus, the final columns of tables 1 and 2 report the Wald statistic for Andrews and Fair's (1988) test for parameter stability in nonlinear econometric models like those estimated here: this test statistic is formed by squaring the difference between parameter estimates across subsamples and dividing the result by the sum of the squares of the corresponding standard errors. Under the null hypothesis of parameter stability, this test statistic is asymptotically distributed as a chi-square random variable with one degree of freedom.

In both the unconstrained, sticky-price model and the constrained, flexible- 
price model, some evidence does appear of a significant change in the monetary policy rule across the 1979 breakpoint. Using the estimates from the sticky-price model, the $p$-value for the test of the null hypothesis of parameter stability is less than 0.10 for $\omega_{\mu}$ and less than 0.05 for $\rho_{v}$. Using the estimates from the flexible-price model, the $p$-value for the test of stability is less than 0.05 for $\omega_{\mu}$ and less than 0.10 for $\omega_{\pi}$. In general, and broadly consistent with the results from Clarida, Gali, and Gertler (2000), it appears that the Federal Reserve has more aggressively adjusted the interest rate in response to changes in money growth and inflation in the post-1979 period.

On the other hand, instability also appears in some of the model's nonpolicy parameters. In both the sticky-price and flexible-price cases, the Wald test decisively rejects the null hypothesis of stability for the discount factor $\beta$, the capital adjustment cost parameter $\phi_{k}$, and several of the parameters governing the size and persistence of the exogenous nonpolicy shocks. Thus, while estimates from both the sticky-price and flexible-price models attribute some of the changing correlations between nominal and real variables to shifts in Federal Reserve policy, those estimates also suggest that other structural changes, unrelated to monetary policy, have played an important role as well. 


\section{Conclusion}

The maximum likelihood estimates, the formal statistical hypothesis tests, and the less formal diagnostic procedures described above all indicate that the postwar US data prefer a model featuring nominal price rigidity to one with purely flexible prices. These results obtain despite the fact that both the sticky-price and the flexible-price models attribute most of the observed variation in the money growth rate and the short-term nominal interest rate to the Federal Reserve's deliberate policy response to the other, nonmonetary shocks that have hit the economy. These results, therefore, provide definitive answers to the questions posed at the outset: evidently, the introduction of nominal price rigidity helps in allowing a model of endogenous money to account for the correlations between nominal and real variables found in the postwar US data.

But while the results do lend empirical support to sticky-price models of the business cycle, it should also be noted that the maximum likelihood estimates of the nominal price adjustment cost parameters obtained here, while large and statistically significant, are associated with rather sizeable standard errors, indicating that considerable uncertainty remains about the absolute degree of nominal price rigidity that is present in the US economy. In addition, although the sticky-price 
model that is developed here potentially allows monetary policy disturbances to have large effects on the real economy, the estimated model suggests that, in practice, such shocks have played a minimal role in driving output fluctuations over the postwar period. Thus, these results may also explain why purely real business cycle models such as Prescott's (1986) successfully replicate many features of the postwar American business cycle.

The empirical results obtained here confirm that important changes in the correlations between nominal and real variables can be found in the US data, looking across pre-1979 and post-1979 subsamples. Previous studies by Bryan and Gavin (1994), Gavin and Kydland (1999), and Clarida, Gali, and Gertler (2000) attribute these changes to the important shift in monetary policy that is widely believed to have followed the appointment of Paul Volker as Federal Reserve Chairman and, indeed, the statistical tests from above detect evidence of instability in the parameters describing Federal Reserve policy before and after 1979. On the other hand, the same tests also detect evidence of instability in the some of the model's other parameters, describing private agents' tastes and technologies as well as the size and persistence of nonmonetary shocks.

Thus, the theoretical and empirical analyses conducted here suggest that important structural changes have taken place in the US economy since 1979 
changes that go beyond a shift in the way that monetary policy is conducted. Identifying the source of these structural changes, and understanding their full impact on the performance of the American economy, remain outstanding tasks for future research.

\section{References}

Andrews, D.W.K., Fair, R.C., 1988. Inference in nonlinear econometric models with structural change, Review of Economic Studies 55, 615-639.

Ball, L., Mankiw, N.G., 1994. A sticky-price manifesto, Carnegie-Rochester Conference Series on Public Policy 41, 127-151.

Blanchard, O.J., Kahn, C.M., 1980. The solution of linear difference models under rational expectations, Econometrica 48, 1305-1311.

Bryan, M.F., Gavin, W.T., 1994. A different kind of money illusion: the case of long and variable lags, Journal of Policy Modeling 16, 529-540.

Casares, M., McCallum, B.T., 2000. An optimizing IS-LM framework with endogenous investment, Working Paper 7908, National Bureau of Economic Research. 
Clarida, R., Gali J., Gertler, M., 2000. Monetary policy rules and macroeconomic stability: evidence and some theory, Quarterly Journal of Economics 115, $147-180$.

Coleman, W.J. II, 1996. Money and output: a test of reverse causation, American Economic Review 86, 90-111.

Ellison, M., Scott A., 2000. Sticky prices and volatile output, Journal of Monetary Economics 46, 621-632.

Finn, M.G., 1996. A theory of the capacity utilization/inflation relationship, Federal Reserve Bank of Richmond Economic Quarterly 82, 67-86.

Finn, M.G., 1999. An equilibrium theory of nominal and real exchange rate comovement, Journal of Monetary Economics 44, 453-475.

Freeman, S., 1986. Inside money, monetary contractions, and welfare, Canadian Journal of Economics 19, 87-98.

Freeman, S., Huffman, G.W., 1991. Inside money, output, and causality, International Economic Review 32, 645-667.

Freeman, S., Kydland, F.E., 2000. Monetary aggregates and output, American Economic Review 90, 1125-1135. 
Friedman, M., Schwartz, A.J., 1963. A Monetary History of the United States, 1867-1960 (Princeton University Press, Princeton).

Fuhrer, J., Moore, G., 1995. Inflation persistence, Quarterly Journal of Economics 110, 127-159.

Gali, J., Gertler, M., 1999. Inflation dynamics: a structural econometric analysis, Journal of Monetary Economics 44, 195-222.

Gavin, W.T., Kydland, F.E., 1999. Endogenous money supply and the business cycle, Review of Economic Dynamics 2, 347-369.

Greenwood, J., Hercowitz, Z., Huffman, G.W., 1988. Investment, capacity utilization, and the real business cycle, American Economic Review 78, 402417.

Greenwood, J., Huffman, G.W., 1987. A dynamic equilibrium model of inflation and unemployment, Journal of Monetary Economics 19, 203-228.

Hairault, J.O., Portier, F., 1993. Money, new-Keynesian macroeconomics and the business cycle, European Economic Review 37, 1533-1568.

Hamilton, J.D., 1994. Time Series Analysis (Princeton University Press, Princeton). 
Ingram, B.F., Kocherlakota, N.R., Savin, N.E., 1994. Explaining business cycles: a multiple-shock approach, Journal of Monetary Economics 34, 415-428.

Ireland, P.N., 1997. A small, structural, quarterly model for monetary policy evaluation, Carnegie-Rochester Conference Series on Public Policy 47, 83108.

Ireland, P.N., 2000a. Interest rates, inflation, and Federal Reserve policy since 1980, Journal of Money, Credit, and Banking 32, 417-434.

Ireland, P.N., 2000b. A method for taking models to the data, Manuscript, Boston College, Department of Economics.

Ireland, P.N., 2001a. Sticky-price models of the business cycle: specification and stability, Journal of Monetary Economics 47, 3-18.

Ireland, P.N., 2001b. Money's role in the monetary business cycle, Working Paper 8115, National Bureau of Economic Research.

Kim, J., 2000. Constructing and estimating a realistic optimizing model of monetary policy, Journal of Monetary Economics 45, 329-359.

Kimball, M.S., 1995. The quantitative analytics of the basic neomonetarist model, Journal of Money, Credit, and Banking 27, 1241-1277. 
King, R.G., Plosser, C.I., 1984. Money, credit, and prices in a real business cycle, American Economic Review 74, 363-380.

King, R.G., Watson, M.W., 1996. Money, prices, interest rates and the business cycle, Review of Economics and Statistics 78, 35-53.

Leeper, E.M., Sims, C.A., 1994. Toward a modern macroeconomic model usable for policy analysis, in: Fischer, S., Rotemberg, J.J., eds., NBER Macroeconomics Annual 1994 (MIT Press, Cambridge) 81-118.

Leeper, E.M., Sims, C.A., Zha, T., 1996. What does monetary policy do?, Brookings Papers on Economic Activity, 1-63.

McCallum, B.T., 1993. Discretion versus policy rules in practice: two critical points, a comment, Carnegie-Rochester Conference Series on Public Policy $39,215-220$.

McCallum, B.T., 2001. Analysis of the monetary transmission mechanism: methodological issues, in: Deutsche Bundesbank, ed., The Monetary Transmission Process: Recent Developments and Lessons for Europe. (Palgrave, New York) 11-43.

McCallum, B.T., Nelson, E., 1999. An optimizing IS-LM specification for mon- 
etary policy and business cycle analysis, Journal of Money, Credit, and Banking 31, 296-316.

Mehra, Y.P., 1997. A review of the recent behavior of M2 demand, Federal Reserve Bank of Richmond Economic Quarterly 83, 27-43.

Orphanides, A., Porter, R.D., 2000. P* revisited: money-based inflation forecasts with a changing equilibrium velocity, Journal of Economics and Business $52,87-100$.

Poole, W., 1970. Optimal choice of monetary policy instruments in a simple stochastic macro model, Quarterly Journal of Economics 84, 197-216.

Prescott, E.C., 1986. Theory ahead of business-cycle measurement, CarnegieRochester Conference Series on Public Policy 25, 11-44.

Roberts, J.M., Stockton, D.J., Struckmeyer, C.S., 1994. Evidence on the flexibility of prices, Review of Economics and Statistics 76, 142-150.

Rotemberg, J.J., 1982. Sticky prices in the United States, Journal of Political Economy 90, 1187-1211.

Rotemberg, J.J., 1996. Prices, output, and hours: an empirical analysis based on a sticky price model, Journal of Monetary Economics 37, 505-533. 
Rotemberg, J.J., Woodford, M., 1997. An optimization-based econometric framework for the evaluation of monetary policy, in: Bernanke, B.S., Rotemberg, J.J., eds., NBER Macroeconomics Annual 1997 (MIT Press, Cambridge) 297-346.

Sbordone, A.M., 2002. Prices and unit labor costs: a new test of price stickiness, Journal of Monetary Economics 49, 265-292.

Taylor, J.B., 1993. Discretion versus policy rules in practice, Carnegie-Rochester Conference Series on Public Policy 39, 195-214.

Taylor, J.B., ed., 1999. Monetary Policy Rules (University of Chicago Press, Chicago).

Tobin, J., 1970. Money and income: post hoc ergo propter hoc?, Quarterly Journal of Economics 84, 301-317.

Yun, T., 1996. Nominal price rigidity, money supply endogeneity, and business cycles, Journal of Monetary Economics 37, 345-370. 
Table 1. Maximum Likelihood Estimates, Sticky-Price Model

\begin{tabular}{cccccc} 
Parameter & Pre-1979 & \multicolumn{3}{c}{ Post-1979 } & \\
& Estimate & Std Error & Estimate & Std Error & $W$ \\
$\beta$ & 0.9980 & 0.0008 & 0.9916 & 0.0010 & $25.9299^{* * *}$ \\
$\gamma$ & 0.0736 & 0.0620 & 0.0345 & 0.0075 & 0.3907 \\
$\alpha$ & 0.2022 & 0.0058 & 0.2119 & 0.0081 & 0.9421 \\
$\phi_{p}$ & 54.0745 & 22.8094 & 161.8345 & 78.5783 & 1.7345 \\
$\phi_{k}$ & 12.4368 & 3.7919 & 32.1346 & 2.5833 & $18.4308^{* * *}$ \\
$\mu$ & 1.0110 & 0.0098 & 1.0088 & 0.0015 & 0.0500 \\
$\omega_{r}$ & 3.0296 & 0.3747 & 2.2974 & 0.2733 & 2.4921 \\
$\omega_{\mu}$ & 0.9840 & 0.1437 & 1.3014 & 0.1244 & $2.7870^{*}$ \\
$\omega_{y}$ & -0.0239 & 0.0169 & -0.0157 & 0.0282 & 0.0621 \\
$\omega_{\pi}$ & 2.0070 & 0.3761 & 2.2102 & 0.4029 & 0.1360 \\
$e$ & 2.7599 & 0.7420 & 3.8975 & 0.1437 & 2.2655 \\
$z$ & 7034.6 & 440.8 & 7090.8 & 650.0 & 0.0051 \\
$\rho_{a}$ & 0.9903 & 0.0158 & 0.9026 & 0.0304 & $6.5424^{* *}$ \\
$\rho_{e}$ & 0.9497 & 0.0290 & 0.9790 & 0.0178 & 0.7413 \\
$\rho_{x}$ & 0.6975 & 0.0904 & 0.9539 & 0.0301 & $7.2332^{* * *}$ \\
$\rho_{z}$ & 0.9787 & 0.0162 & 0.9465 & 0.0231 & 1.3135 \\
$\rho_{v}$ & 0.4400 & 0.0603 & 0.1984 & 0.0894 & $5.0217^{* *}$ \\
$\sigma_{a}$ & 0.0064 & 0.0074 & 0.0186 & 0.0021 & 2.5453 \\
$\sigma_{e}$ & 0.0115 & 0.0017 & 0.0076 & 0.0006 & $4.7501^{* *}$ \\
$\sigma_{x}$ & 0.0224 & 0.0099 & 0.2127 & 0.0824 & $5.2535^{* *}$ \\
$\sigma_{z}$ & 0.0153 & 0.0024 & 0.0202 & 0.0048 & 0.8228
\end{tabular}

Notes: $W$ denotes the Wald statistic for Andrews and Fair's (1988) test for parameter stability across subsamples. ${ }^{*},{ }^{* *}$, and ${ }^{* * *}$ indicate that the $p$ value for the test is less than $0.10,0.05$, and 0.01 . 
Table 2. Maximum Likelihood Estimates, Flexible-Price Model

\begin{tabular}{cccccc} 
Parameter & Pre-1979 & \multicolumn{3}{c}{ Post-1979 } & \\
& Estimate & Std Error & Estimate & Std Error & $W$ \\
$\beta$ & 0.9981 & 0.0005 & 0.9913 & 0.0007 & $62.2476^{* * *}$ \\
$\gamma$ & 0.0280 & 0.0166 & 0.0250 & 0.0064 & 0.0279 \\
$\alpha$ & 0.2045 & 0.0053 & 0.2177 & 0.0093 & 1.5125 \\
$\phi_{p}$ & 0 & - & 0 & - & - \\
$\phi_{k}$ & 1.9271 & 0.9925 & 17.4075 & 4.1013 & $13.4591^{* * *}$ \\
$\mu$ & 1.0113 & 0.0059 & 1.0088 & 0.0011 & 0.1719 \\
$\omega_{r}$ & 2.8129 & 0.2817 & 2.6350 & 0.2547 & 0.2194 \\
$\omega_{\mu}$ & 0.4278 & 0.1306 & 0.8219 & 0.1435 & $4.1265^{* *}$ \\
$\omega_{y}$ & -0.0043 & 0.0218 & -0.0211 & 0.0401 & 0.1354 \\
$\omega_{\pi}$ & 2.5318 & 0.2539 & 3.3773 & 0.3578 & $3.7136^{*}$ \\
$e$ & 3.3733 & 0.2428 & 4.0382 & 0.1347 & $5.7356^{* *}$ \\
$z$ & 7038.6 & 363.7 & 6927.9 & 247.4 & 0.0633 \\
$\rho_{a}$ & 0.9879 & 0.0130 & 0.7939 & 0.0342 & $28.1111^{* * *}$ \\
$\rho_{e}$ & 0.9456 & 0.0279 & 0.9750 & 0.0187 & 0.7646 \\
$\rho_{x}$ & 0.9475 & 0.0726 & 0.9478 & 0.0404 & 0.0000 \\
$\rho_{z}$ & 0.9457 & 0.0368 & 0.9571 & 0.0151 & 0.0827 \\
$\rho_{v}$ & 0.1840 & 0.0689 & 0.1645 & 0.0922 & 0.0287 \\
$\sigma_{a}$ & 0.0134 & 0.0035 & 0.0194 & 0.0018 & 2.3003 \\
$\sigma_{e}$ & 0.0092 & 0.0008 & 0.0075 & 0.0006 & $3.1138^{*}$ \\
$\sigma_{x}$ & 0.0057 & 0.0024 & 0.0449 & 0.0146 & $7.0526^{* * *}$ \\
$\sigma_{z}$ & 0.0082 & 0.0023 & 0.0094 & 0.0011 & 0.2074
\end{tabular}

Notes: $W$ denotes the Wald statistic for Andrews and Fair's (1988) test for parameter stability across subsamples. ${ }^{*},{ }^{* *}$, and ${ }^{* * *}$ indicate that the $p$ value for the test is less than $0.10,0.05$, and 0.01 . 
Table 3. Standard Deviations, Models and Data Pre-1979

$\begin{array}{cccc}\text { Variable } & \text { Data } & \begin{array}{c}\text { Sticky-Price } \\ \text { Model }\end{array} & \begin{array}{c}\text { Flexible-Price } \\ \text { Model }\end{array} \\ \text { Detrended Output } & 0.0427 & 0.0790 & 0.0519 \\ \text { Money Growth } & 0.0081 & 0.0137 & 0.0131 \\ \text { Inflation } & 0.0072 & 0.0112 & 0.0089 \\ \text { Nominal Interest Rate } & 0.0046 & 0.0105 & 0.0082 \\ \text { Post-1979 } & & & \\ \text { Variable } & & & \text { Flexible-Price } \\ & \text { Data } & \text { Model } & \text { Model } \\ \text { Detrended Output } & 0.0349 & 0.1277 & 0.0449 \\ \text { Money Growth } & 0.0082 & 0.0099 & 0.0112 \\ \text { Inflation } & 0.0035 & 0.0040 & 0.0044 \\ \text { Nominal Interest Rate } & 0.0058 & 0.0057 & 0.0042\end{array}$


Table 4. Variance Decompositions, Sticky-Price Model

\begin{tabular}{|c|c|c|c|c|c|}
\hline \multicolumn{6}{|l|}{ Pre-1979 } \\
\hline Variable & $\begin{array}{c}\text { Preference } \\
\text { Shock } a_{t}\end{array}$ & $\begin{array}{c}\text { Money } \\
\text { Demand } \\
\text { Shock } e_{t}\end{array}$ & $\begin{array}{l}\text { Investment } \\
\text { Efficiency } \\
\text { Shock } x_{t}\end{array}$ & $\begin{array}{l}\text { Productivity } \\
\text { Shock } z_{t}\end{array}$ & $\begin{array}{l}\text { Monetary } \\
\text { Policy } \\
\text { Shock } v_{t}\end{array}$ \\
\hline Detrended Output & 1.7 & 0.5 & 1.2 & 95.7 & 0.9 \\
\hline Money Growth & 53.0 & 7.1 & 0.8 & 18.9 & 20.1 \\
\hline Inflation & 81.9 & 3.8 & 0.5 & 7.7 & 6.0 \\
\hline Nominal Interest Rate & 86.1 & 5.1 & 0.2 & 8.6 & 0.1 \\
\hline \multicolumn{6}{|l|}{ Post-1979 } \\
\hline Variable & $\begin{array}{l}\text { Preference } \\
\text { Shock } a_{t}\end{array}$ & $\begin{array}{c}\text { Money } \\
\text { Demand } \\
\text { Shock } e_{t}\end{array}$ & $\begin{array}{c}\text { Investment } \\
\text { Efficiency } \\
\text { Shock } x_{t}\end{array}$ & $\begin{array}{c}\text { Productivity } \\
\text { Shock } z_{t}\end{array}$ & $\begin{array}{l}\text { Monetary } \\
\text { Policy } \\
\text { Shock } v_{t}\end{array}$ \\
\hline Detrended Output & 1.4 & 0.3 & 83.0 & 14.9 & 0.3 \\
\hline Money Growth & 12.3 & 4.9 & 21.7 & 23.7 & 37.3 \\
\hline Inflation & 32.7 & 3.7 & 21.2 & 34.4 & 8.1 \\
\hline Nominal Interest Rate & 45.1 & 2.7 & 41.8 & 9.5 & 1.0 \\
\hline
\end{tabular}

Note: Each figure corresponds to the percentage of the variance of each variable attributed to each shock. 
Table 5. Variance Decompositions, Flexible-Price Model

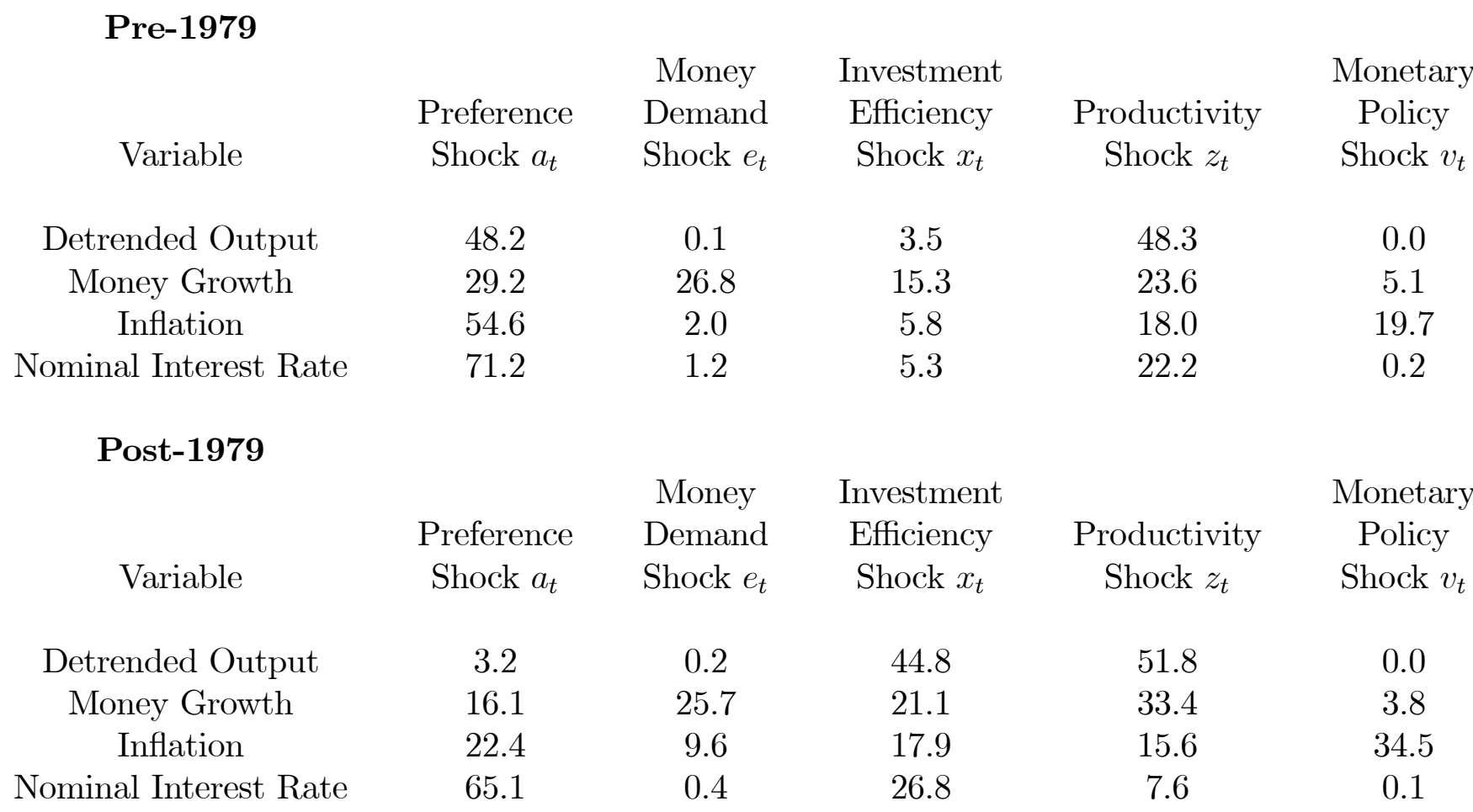

Note: Each figure corresponds to the percentage of the variance of each variable attributed to each shock. 

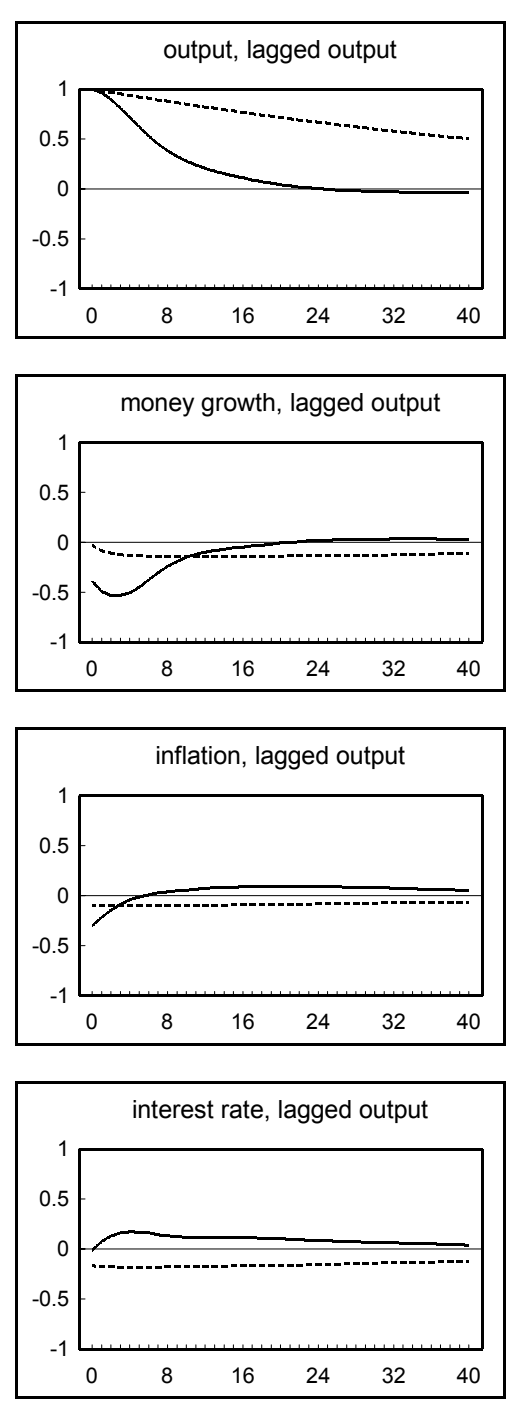
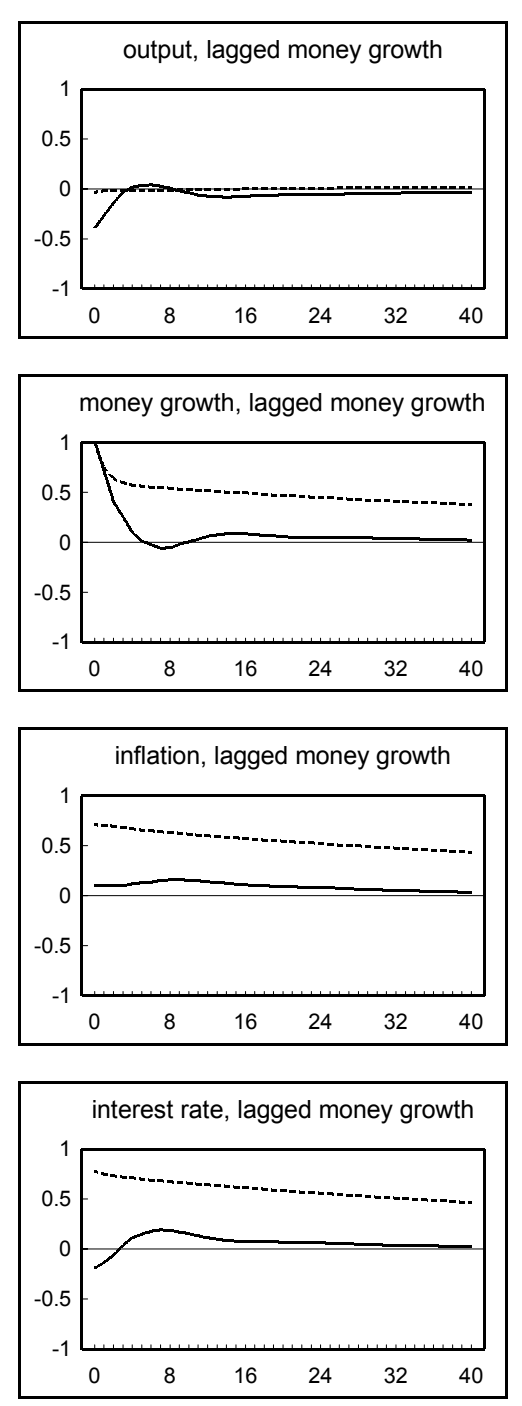
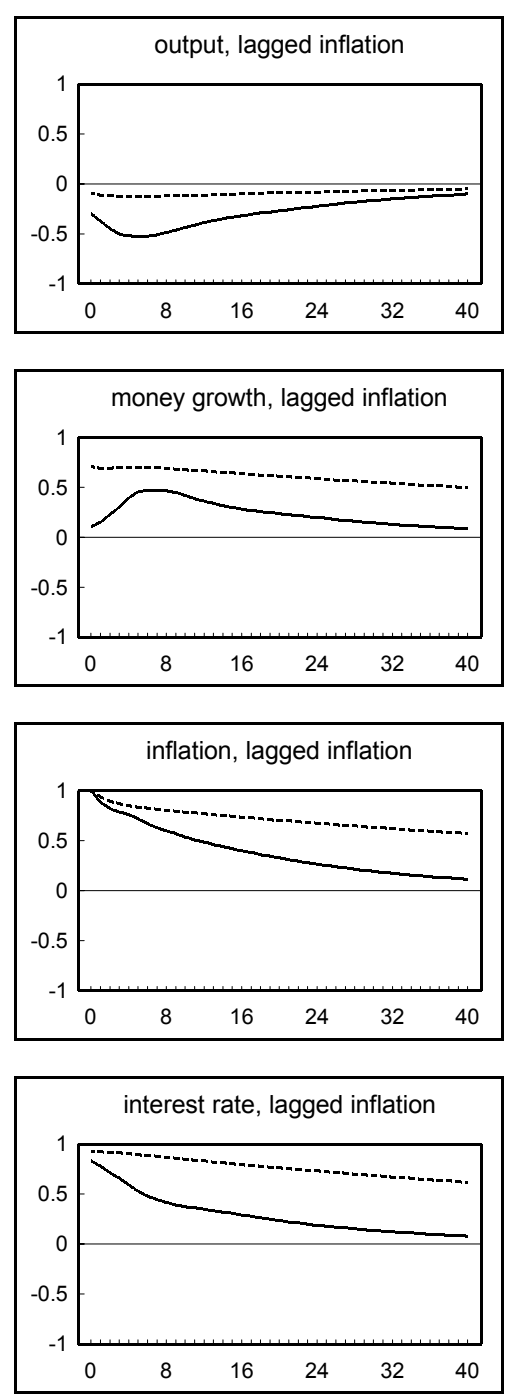
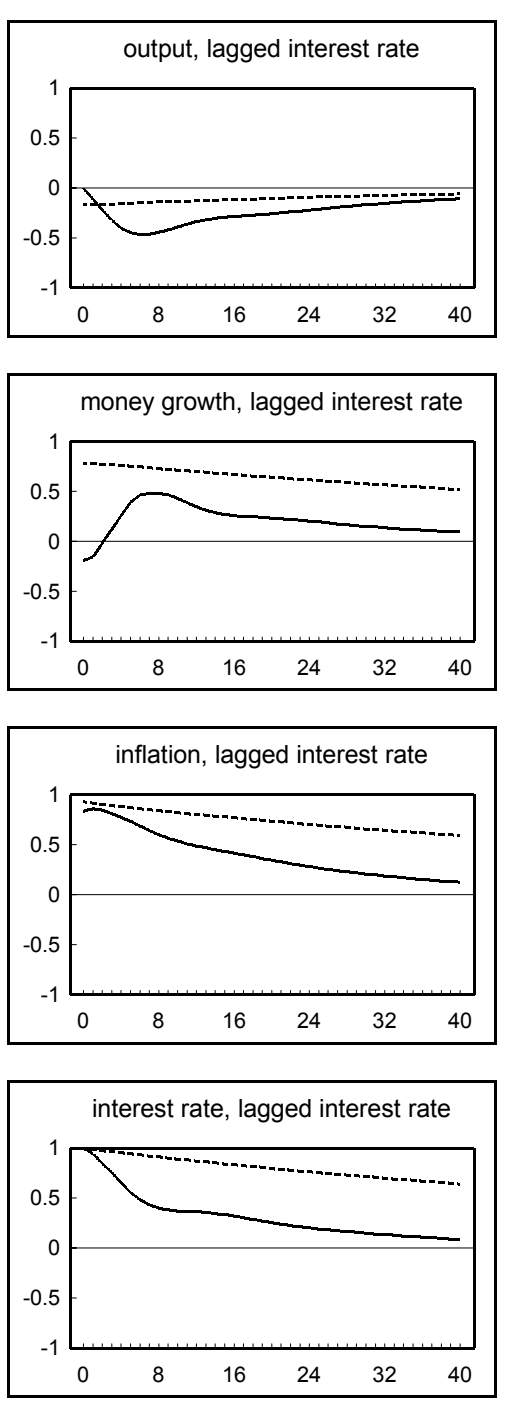

Figure 1. Vector Autocorrelation Functions, Pre-1979, Sticky-Price Model (dashed line) and Data (solid line) 

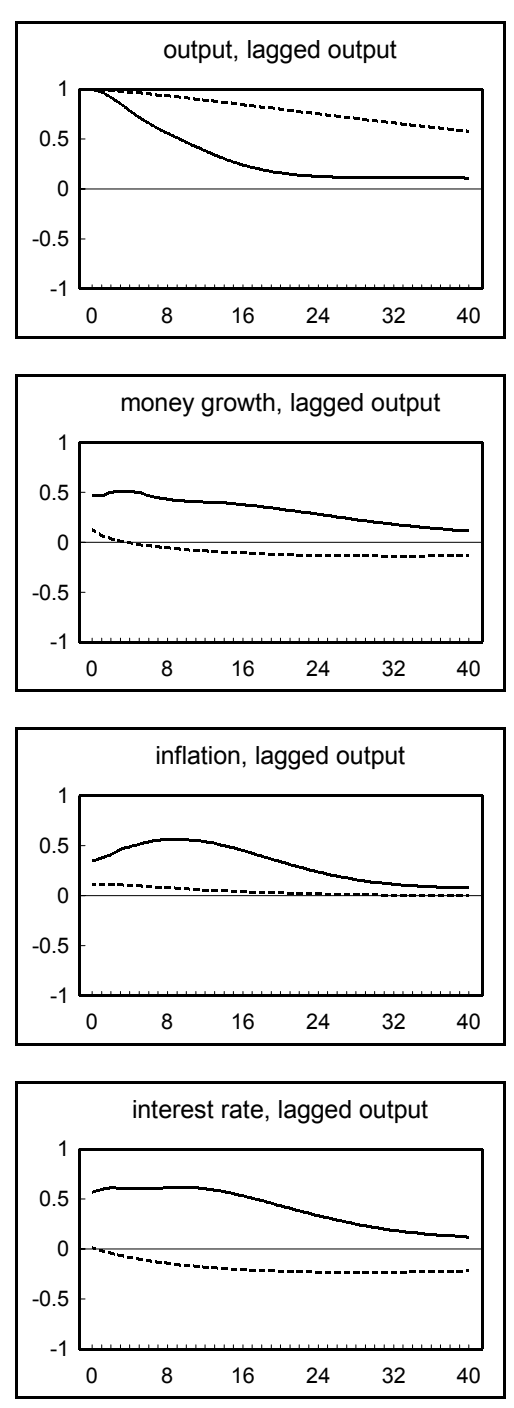
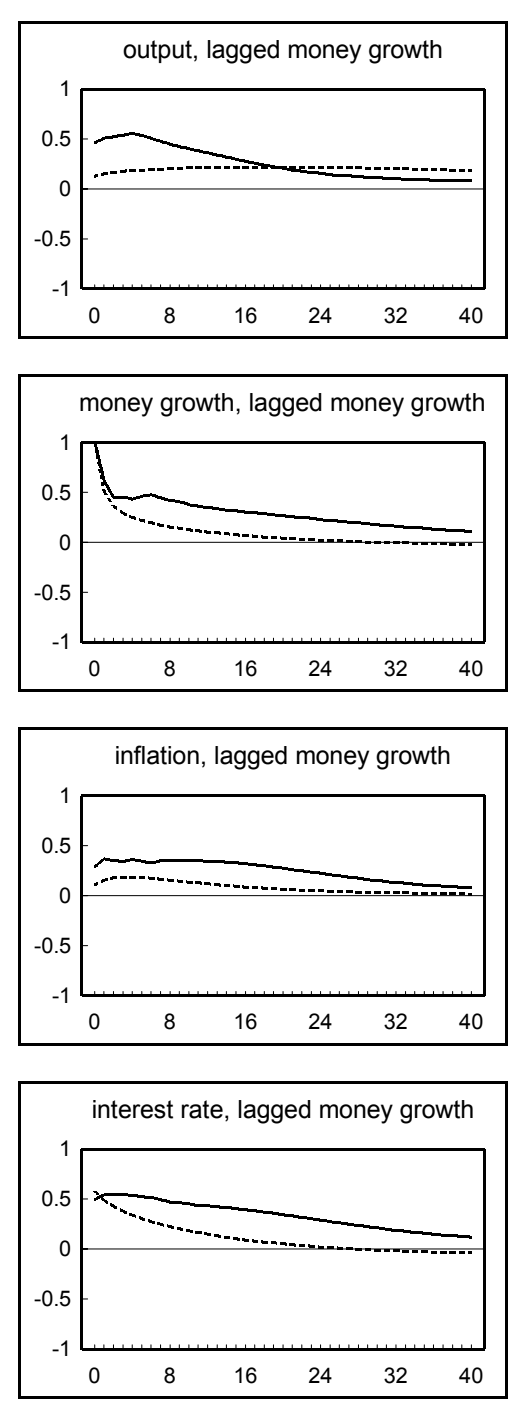
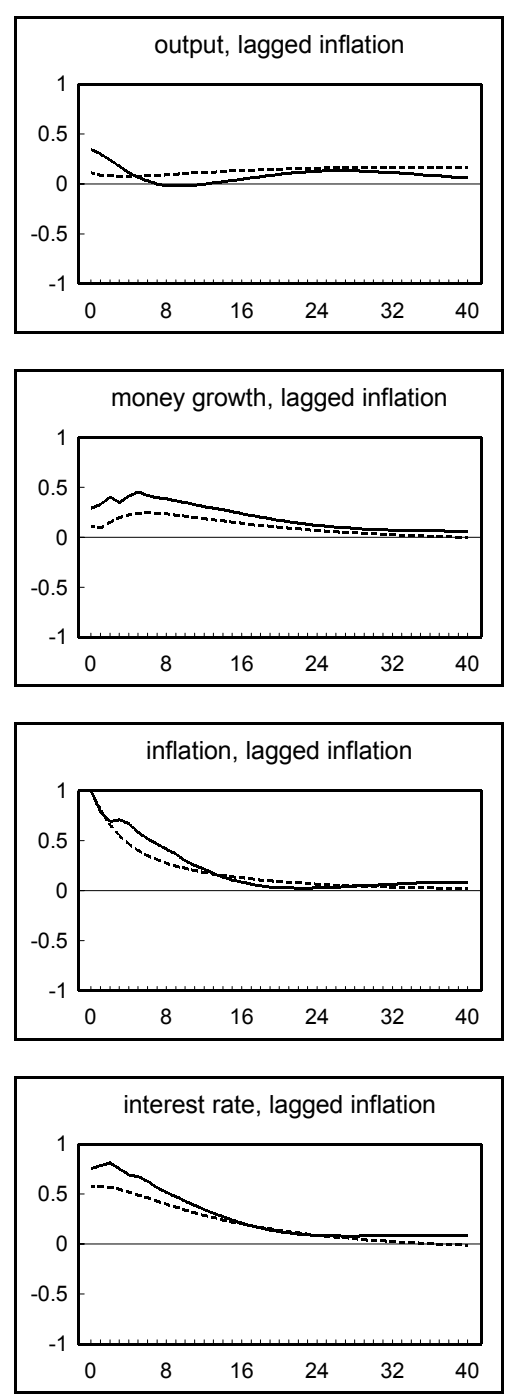
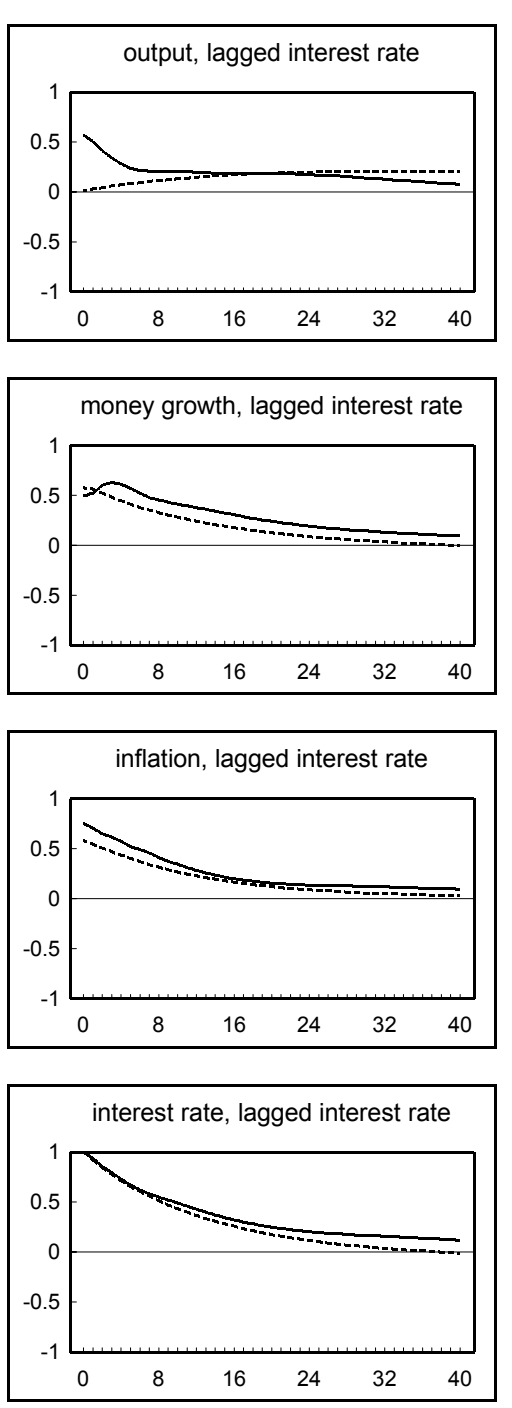

Figure 2. Vector Autocorrelation Functions, Post-1979, Sticky-Price Model (dashed line) and Data (solid line) 

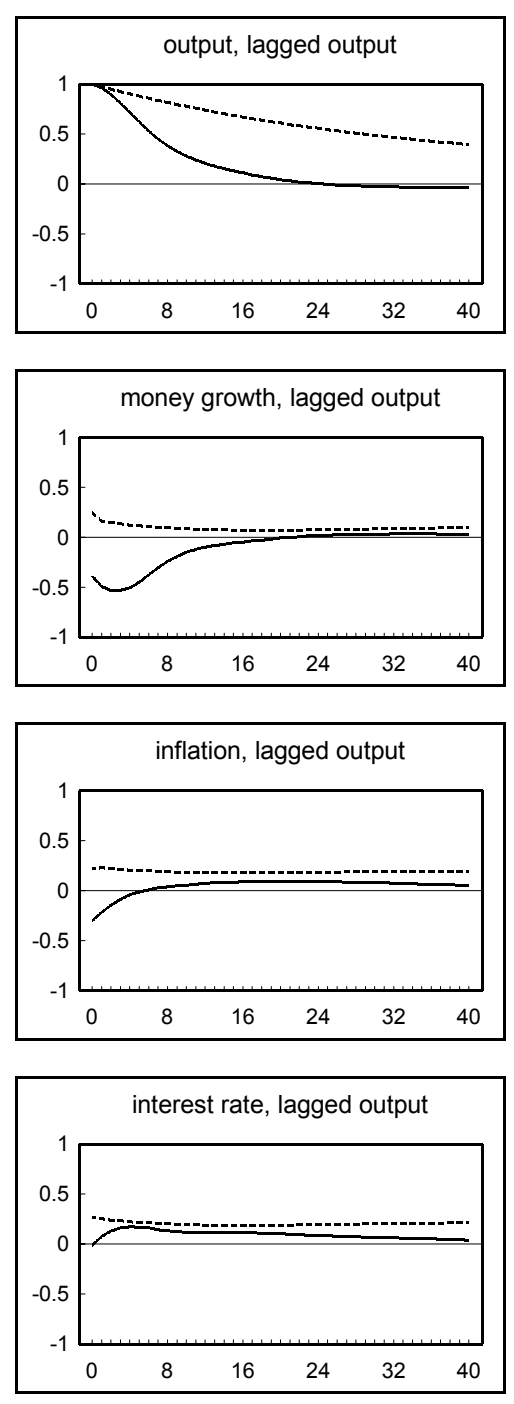
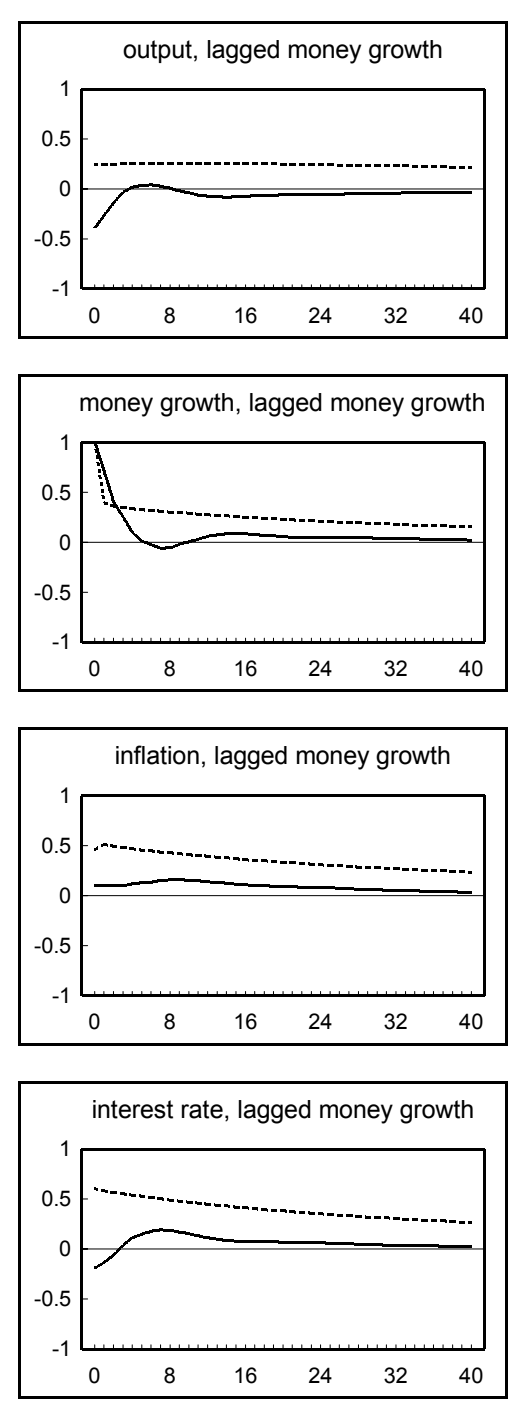
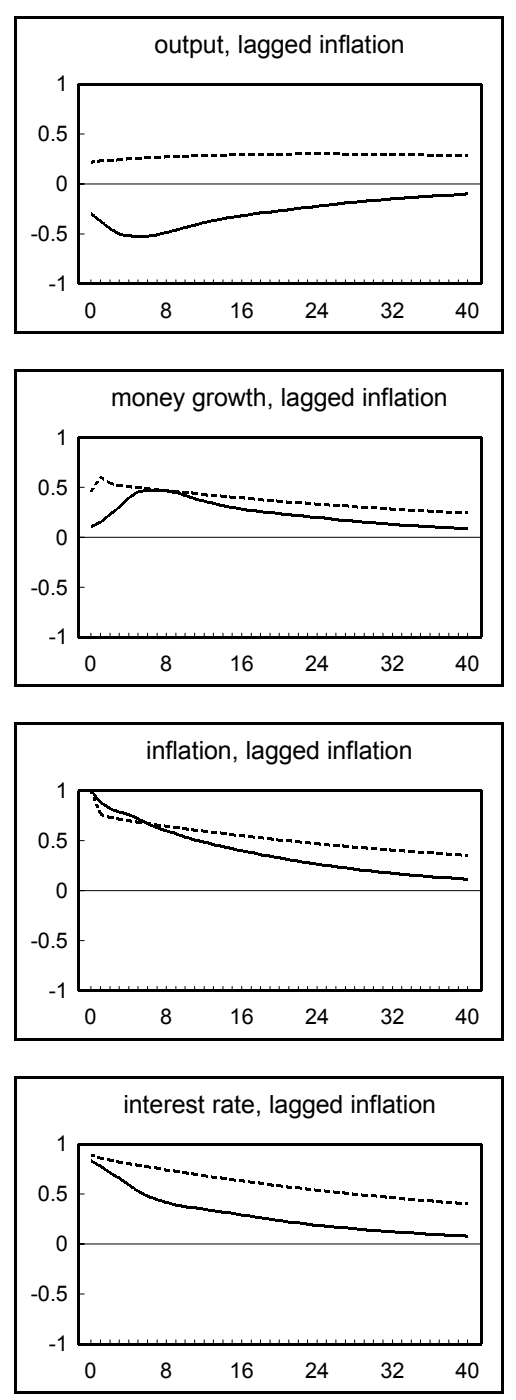
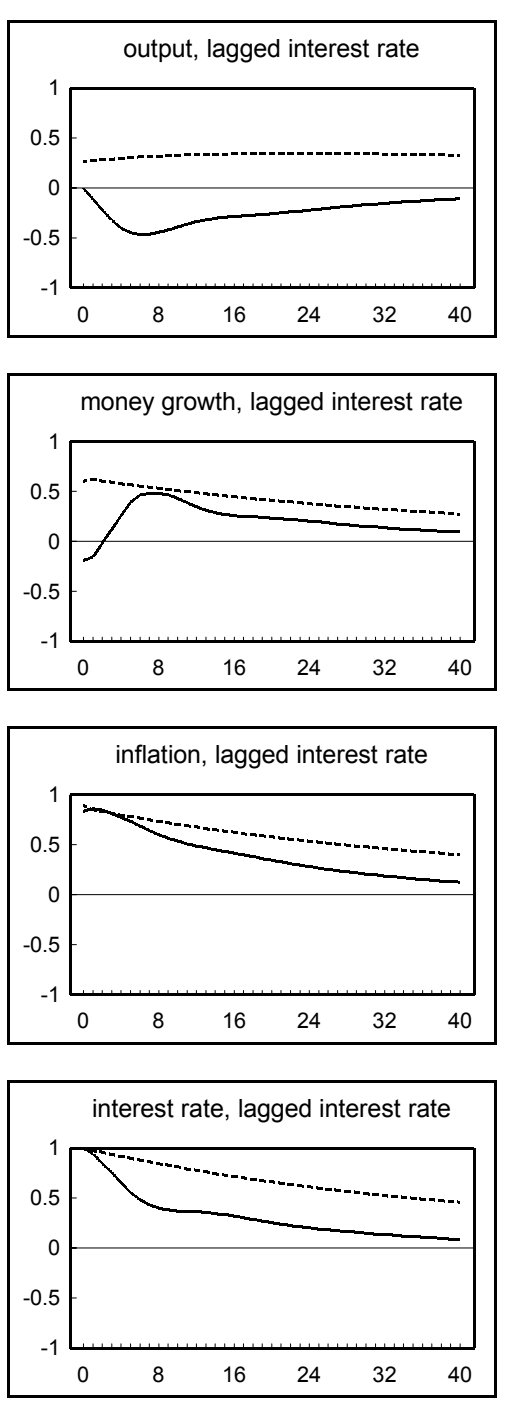

Figure 3. Vector Autocorrelation Functions, Pre-1979, Flexible-Price Model (dashed line) and Data (solid line) 

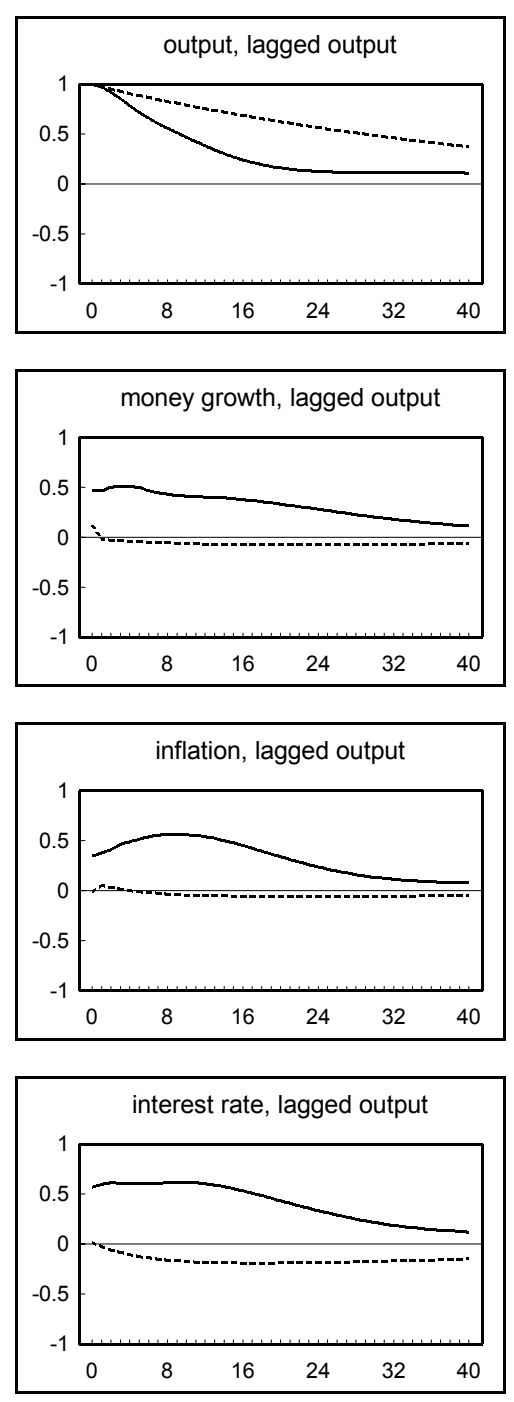
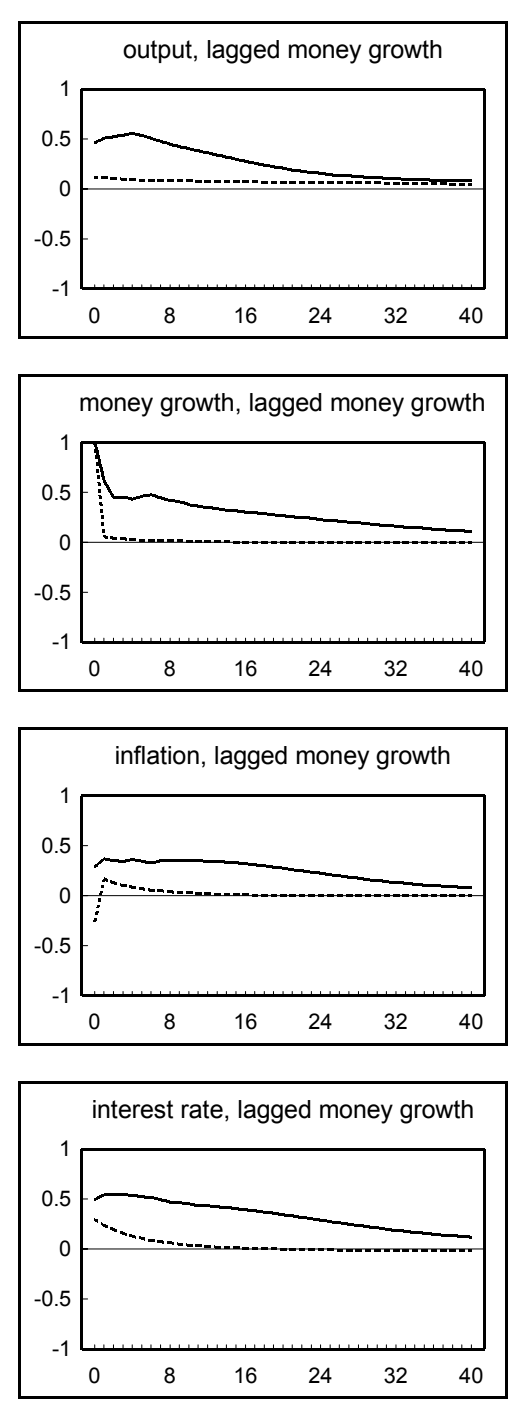
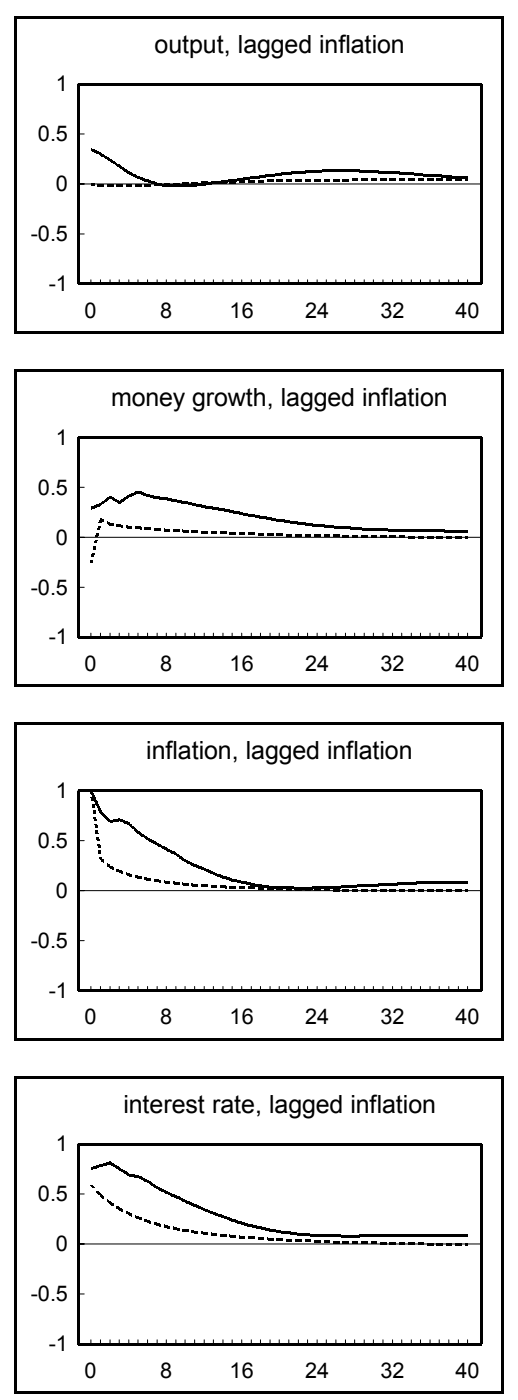
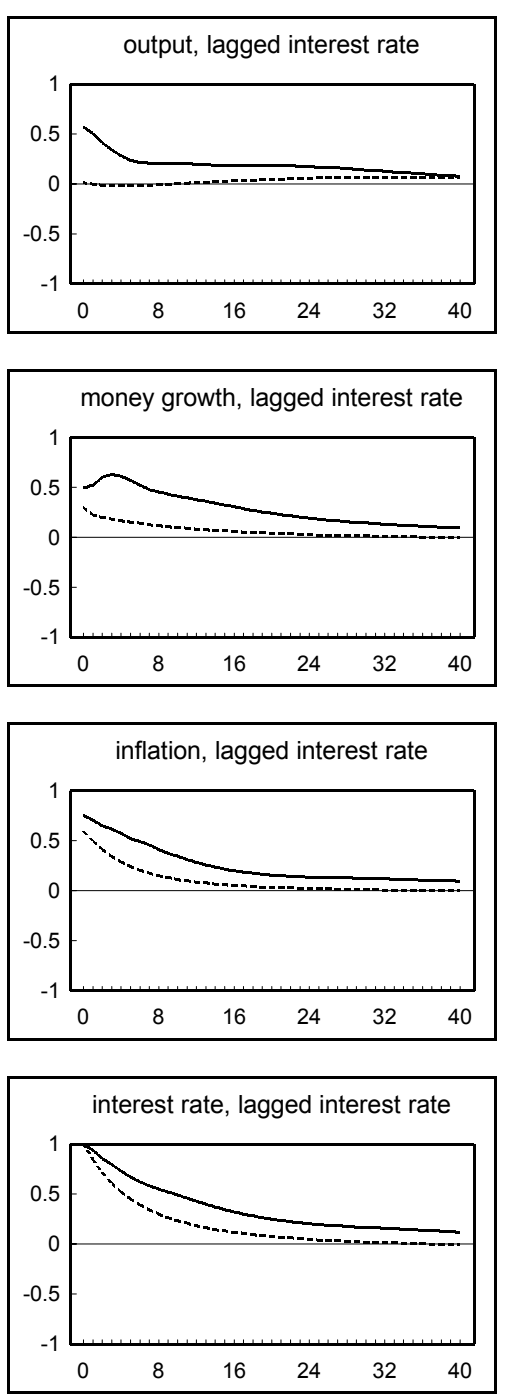

Figure 4. Vector Autocorrelation Functions, Post-1979, Flexible-Price Model (dashed line) and Data (solid line) 